\title{
Porphyromonas gingivalis and Aggregatibacter actinomycetemcomitans IgG Subclass Antibody Levels as Immunological Risk Indicators of Chronic Periodontitis: A Multilevel Approach
}

\author{
Niveles de Anticuerpos Subclase IgG de Porphyromonas gingivalis y Aggregatibacter \\ actinomycetemcomitans como Indicadores de Riesgo Inmunológico de Periodontitis \\ Crónica: un Enfoque Multinivel
}

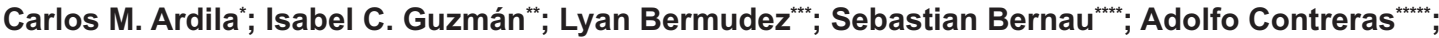

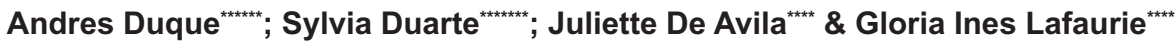

\begin{abstract}
ARDILA, C. M.; GUZMÁN, I. C.; BERMUDEZ, L.; BERNAU, S.; CONTRERAS, A.; DUQUE, A.; DUARTE, S.; DE AVILA, J. \& LAFAURIE, G. I. Porphyromonas gingivalis and Aggregatibacter actinomycetemcomitans IgG subclass antibody levels as immunological risk indicators of chronic periodontitis: a multilevel approach. Int. J. Odontostomat., 7(3):433-440, 2013.

ABSTRACT: Antibody levels to some periodontal pathogens are associated with enhanced levels of inflammatory markers. The purpose of the current study was to examine the relative contribution of serum immunoglobulin $\mathrm{G}$ (IgG) subclass antibody level factors and local factors on the probing pocket depth in chronic periodontitis. Serum samples were taken from 444 patients diagnosed with moderate and severe periodontitis and 223 control subjects. The IgG subclass antibody titers to Porphyromonas gingivalis (Pg), Aggregatibacter actinomycetemcomitans (Aa) and Tanerella forsythia (Tf) using indirect immunoassay (ELISA) were determined. The relative contribution of patient, tooth and site-associated parameters on the probing pocket depth were evaluated with a hierarchical multilevel model. The results indicated that periodontitis patients had detectable levels of IgG1 and IgG2. High IgG1 and IgG2 antibody levels against Aa occurred in 132 and 142 periodontitis patients, respectively. High IgG1 and IgG2 antibody levels against Pg occurred in 141 and 138 , periodontitis patients, respectively, and High IgG1 and IgG2 antibody levels against Tf occurred in 121 and 136 periodontitis patients, respectively. The majority of the variance was attributed to the site level (48\%). The multilevel analysis associated deeper probing depth with subject factors (serum IgG1 and IgG2 antibody to Pg and Aa), tooth factors (tooth type), and site factors (mesial-distal location and bleeding on probing). Elevated serum IgG1 and IgG2 antibody to Pg and Aa (subject factors) reflects destructive periodontal disease status.
\end{abstract}

KEY WORDS: IgG subclass, periodontitis, antibody, multilevel analysis.

\section{INTRODUCTION}

Chronic periodontitis is the consequence of interactions between specific subgingival bacterial species and multilateral host responses to the infection. Additionally, it has been shown that antibody levels to some periodontal pathogens are associated with enhanced levels of inflammatory markers and incidence of cardiovascular diseases (Holmlund et al., 2011; Rams et al., 2006). The assessment of these antibodies in longitudinal studies also suggests a relationship between this measure of the host response and disease progression at both subject and site levels (Kinane et al., 1999). These findings sustain the

Ph.D in Epidemiology, Titular Professor, School of Dentistry, University of Antioquia, Medellín, Colombia.

** Periodontist of Universidad de Chile and Professor of University of Antioquia, Medellín, Colombia.

*** Dentist. School of Dentistry, University of Antioquia, Medellín, Colombia.

*m** Basic-Oral Research Unit-UIBO, El Bosque University, Colombia.

Ph.D. Periodontal Medicine Group, University of Valle, Colombia.

Periodontist. CES University, Colombia.

******** Periodontist. Javeriana University, Colombia. 
ARDILA, C. M.; GUZMÁN, I. C.; BERMUDEZ, L.; BERNAU, S.; CONTRERAS, A.; DUQUE, A.; DUARTE, S.; DE AVILA, J. \& LAFAURIE, G. I. Porphyromonas gingivalis and Aggregatibacter actinomycetemcomitans IgG subclass antibody levels as immunological risk indicators of chronic periodontitis: a multilevel approach. Int. J. Odontostomat., 7(3):433-440, 2013.

concept that antibody may confirm to be a marker of disease activity. As pointed out by Craig et al. (2002), the identification of microbial and immunological risk factors for destructive periodontal diseases would enable intervention to be targeted to those individuals and sites at risk for disease progression. On the other hand, it has been documented that it is difficult to identify periodontal disease activity and to predict the occurrence of disease progression for a site or subject by means of clinical methods of evaluation. Consequently, it is not necessary for risk factors to play the equivalent role in predicting disease progression both at the site and subject level (Tu et al., 2004).

Sites that show increasing pocket depth and progressive attachment loss in established chronic periodontitis have been related with the increased prevalence of several Gram-negative species, including Porphyromonas gingivalis, Aggregatibacter actinomycetemcomitans and Tanerella forsythia. Serum antibody to periodontal pathogens has been used to support identification of microbial species that are associated with destructive periodontal disease progression and a majority of the studies concluded that elevated antibody levels are correlated with disease severity (Sakai et al., 2001).

A variety of clinical courses of infectious disease seen may be a consequence of the particular biological properties of a certain immunoglobulin $\mathrm{G}(\mathrm{lgG})$ subclass (Sakai et al., 2001). Protein antigens generally produce IgG1 whereas LPS and polysaccharide antigens tend to stimulate $\lg G 2$ response (Sakai et al., 2001). A longitudinal study indicated strong relationships between antibody levels and disease activity on a subgroup of subjects or individual subject basis (Taubman et al. 1992). However, the precise function of each IgG subclass antibody in periodontal destruction or protection is still not clear. Attempts to use means of full mouth measurements of the subjects in identifying the determinants of this progression have tended to fail due to the large number of inactive sites causing a major dilution of the disease progression (Haffajee \& Socransky, 1986).

Application of multilevel analysis, which takes the clustering effect of periodontal research data into consideration, may supply a more precise elucidation of theaccepted hierarchical structure of the clinical findings of periodontitis and variables on the observed microbiologic-immunological association.

Therefore, the aim of the present study was to evaluate, using a multilevel analysis, the relative contribution of $P$. gingivalis, $A$. actinomycetemcomitans and $T$. forsythia IgG subclass and other subject and local (tooth and site) factors on the probing pocket depth in subjects with chronic periodontitis.

\section{MATERIAL AND METHOD}

Subjects. Six hundred and sixty seven adult patients (444 patients diagnosed with moderate and severe periodontitis, with at least 14 natural teeth; and 223 control-healthy subjects) who attended the dental clinics of the University of Antioquia, CES University, University of Valle, El Bosque University and Javeriana University were recruited from January 2009 to December 2011. Informed and written consent was obtained from each participant. The study design was approved by the Ethics Committee on Human Research of each University. Exclusion criteria included diabetes, autoimmune diseases, pregnant or nursing women, consumption of systemic antimicrobials, nonsteroidal analgesics or anti-inflammatory drugs in the last six months, and periodontal therapy during the last six months.

\section{Clinical Evaluation}

Site parameters: Probing depth (PD) was measured at six sites per tooth (mesiobuccal, buccal, distobuccal, distolingual, lingual and mesiolingual) in all teeth excluding third molars using a calibrated standard probe (UNC-15, Hu-Friedy, Chicago, IL). Measurements for a given subject were made by a trained and calibrated clinician in each university. Gingival index (Loe \& Silness. 1963), presence of plaque and bleeding on probing (BOP) were also assessed at each site. The intra-examiner and interexaminer reproducibility were assessed before and during the study. The intra-class correlation coefficients for mean PD and clinical attachment level (CAL) were $0.85-0.95$ and $0.82-0.90$, respectively. The diagnosis of chronic periodontitis was made based on criteria defined at the workshop sponsored by the American Academy of Periodontology (AAP) (Armitage 1999).

Tooth parameters: A tooth type nominal variable was also included in the analysis (Molarspremolars=posterior teeth; incisors-canines=anterior teeth).

Subject parameters: age, sex, body-mass index 
ARDILA, C. M.; GUZMÁN, I. C.; BERMUDEZ, L.; BERNAU, S.; CONTRERAS, A.; DUQUE, A.; DUARTE, S.; DE AVILA, J. \& LAFAURIE, G. I. Porphyromonas gingivalis and Aggregatibacter actinomycetemcomitans IgG subclass antibody levels as immunological risk indicators of chronic periodontitis: a multilevel approach. Int. J. Odontostomat., 7(3):433-440, 2013.

(BMI), presence of $A$. actinomycetemcomitans, $\mathrm{P}$. gingivalis and $T$. forsythia, serum $\operatorname{lgG} 1$ and $\operatorname{lgG} 2$ antibody to $P$. gingivalis, $A$. actinomycetemcomitans and T. forsythia were included in the multilevel analysis.

Microbial Sampling. Microbial sampling on periodontitis patients was performed on pockets $\geq 5 \mathrm{~mm}$ and the deepest six pockets were selected for sampling, whereas one site in each sextant was chosen for control subjects. After removing supragingival plaque with curettes and isolating the area with cotton pellets, the paper points (Maillefer, Ballaigues, Switzerland) were inserted into each periodontal pocket for 20 seconds. The paper points were transferred to a sterile tube to obtain a pool of samples for polymerase chain reaction (PCR) processing and identification of $P$. gingivalis, $A$. actinomycetemcomitans, and T. forsythia.

PCR was performed as described by Ashimoto et al. (1996) and Saiki et al. (1988). The reaction took place in a final volume of $25 \mathrm{ml}$, from which $5 \mathrm{ml}$ corresponding to the sample and $20 \mathrm{ml}$ to the reaction mixture that contains buffer of PCR $1 \mathrm{X}(50 \mathrm{mM} \mathrm{KCl}, 10$ mMTris- $\mathrm{HCl}\left(\mathrm{pH} 9.0 \mathrm{a} 25^{\circ} \mathrm{C}\right), 1.5 \mathrm{mM} \mathrm{MgCl}$ and $0.1 \%$ of Triton $\circledast X-100), 1.25 \cup$ of Go Taq flexi DNA polymerase (Promega $\left.{ }^{\circledR}\right), 1.5 \mathrm{mM} \mathrm{MgCl}, 0.2 \mathrm{mM}$ of each deoxyribonucleotide and $2 \mathrm{mM}$ of each primer. The temperature cycles in the thermal cycler (MyCycler®Termal Cycler, Bio-Rad) were performed as follows: included an initial step of denaturation at $95^{\circ} \mathrm{C}$ by two minutes followed for 36 cycles at $95^{\circ} \mathrm{C}$ for 30 seconds, $60^{\circ} \mathrm{C}$ by minute and $72^{\circ} \mathrm{C}$ by minute, with a final step at $72^{\circ} \mathrm{C}$ for two minutes. For $A$. actinomycetemcomitans the annealing temperature was changed up to $55^{\circ} \mathrm{C}$ and the final step time was increased 10 minutes. The finding of $P$. gingivalis in the samples was recognized by the presence of a band corresponding to $404 \mathrm{pb}, T$. forsythia to $316 \mathrm{pb}$ and $A$. actinomycetemcomitans to $557 \mathrm{pb}$ in a agarose gel in $1,5 \%$ with $0,5 \mu \mathrm{g} / \mathrm{mL}$ of ethidium bromide. Reference strains of each bacterium were used as positive DNA controls and as negative water control grade one sterile. Indirect Immunoassay (ELISA) for the determination of serum antibodies IgG1 e IgG2 against periodontal pathogens:

Peripheral blood was collected from each subject to determine serum antibodies $\lg \mathrm{G} 1 \mathrm{e} \lg \mathrm{G} 2$ against $P$. gingivalis, $A$. actinomycetemcomitans and $T$. forsythia. ELISA was performed as follows: 96-well plate (Immulux TM HB DYNEX Germany) was covered with $50 \mathrm{~mL}$ in a concentration $10 \mu \mathrm{g} / \mathrm{ml}$ of sonicate of $P$. gingivalis (TCC 33277), T. forsythia (ATCC43037) or
A. actinomycetemcomitans (ATCC 29523) of carbonate buffer $(\mathrm{pH}$ 9.6) and incubated overnight. The plates were blocked for an hour to $37^{\circ} \mathrm{C}$ with $150 \mathrm{~mL}$ of solution of phosphate buffer (PBS, pH: 7,2) with $1 \%$ bovine serum albumin (BSA, Sigma), $1 \%$ milk and avidin (Avidin/Biotin Blocking Kit, Vector Labs). The sera were diluted 1/100 in PBS-Tween-BSA (1\%)-biotin solution (Avidin/Biotin Blocking Kit, Vector Labs) and were incubated at $37^{\circ} \mathrm{C}$ for hour. Anti-lgG1- dilution 1:5000 (Mouse anti-Human IgG1, Invitrogen) or antiIgG2 dilution 1:10000 (Mouse anti-Human IgG2, Sigma) in PBS-Tween-BSA (1\%) solution, were incubated for 1 hour at $37^{\circ} \mathrm{C}$. Streptavidin peroxidase (Invitrogen, USA) in a dilution 1/1500 dilution was incubated for 1 hour at room temperature. Between each incubation period, three washes were carried out with $250 \mu \mathrm{l}$ PBS-tween $(0.05 \%)$ solution for 2 minutes in stirring (Multiwasher-MW2001, SUMA). Finally, 50 $\mu$ l phosphate/citrate buffer solution $(0.5 \mathrm{M}, \mathrm{pH}=5)$ was added with o-Phenylenediamine (OPD-PIERCE) and a concentration of $1 \mathrm{mg} / \mathrm{ml}$ was added and activated with $\mathrm{H}_{2} \mathrm{O}_{2}$ for 5 min at room temperature. The reaction was stopped with a solution of sulphuric acid $(2.5 \mathrm{M})$. Absorbance values were read at $490 \mathrm{~nm}$ (Lector StatFax2100 AWARENESS TECHNOLOGY INC). The concentration of IgG1 and IgG2 in the samples for each of the microorganisms was calculated by linear regression analysis with a known concentration curve $(5 \mu \mathrm{g} / \mathrm{ml}-0,152 \mu \mathrm{g} / \mathrm{ml}$, dilution 1:2) of human immunoglobulin IgG1 o lgG2 (Sigma). Every sample was valued in triplicate.

As described by Rams et al. the $90^{\text {th }}$ percentile of all ELISA A. actinomycetemcomitans, $P$. gingivalis and $T$. forsythia antibody measurements, determined by using an Excel 2010 spreadsheet (Microsoft Corp., Redmond, WA, USA), served as a threshold for the identification of study subjects demonstrating high versus low serum IgG antibody levels to the three study organisms.

All microbiological and immunological laboratory procedures were performed blind, without knowledge of the clinical status of the study subjects or of the periodontal sites sampled.

Statistical Analysis. Data were entered into an Excel 2010 (Microsoft Corp., Redmond, WA, USA) database and were proofed for entry errors. Normal distribution of continuous variables was verified with the Kolmogorov-Smirnov test with Liliefors correction. Categorical data were analyzed with the $\mathrm{X}^{2}$ test. The significance level was set at 0.05 for all tests. 
ARDILA, C. M.; GUZMÁN, I. C.; BERMUDEZ, L.; BERNAU, S.; CONTRERAS, A.; DUQUE, A.; DUARTE, S.; DE AVILA, J. \& LAFAURIE, G. I. Porphyromonas gingivalis and Aggregatibacter actinomycetemcomitans IgG subclass antibody levels as immunological risk indicators of chronic periodontitis: a multilevel approach. Int. J. Odontostomat., 7(3):433-440, 2013.

The influence of different factors on the outcome was investigated with multilevel regression analyses. A three-level random intercept regression model was constructed: site at level 1, tooth at level 2 and subject at level 3. This technique allows the identification of single-tooth effects or parameters while still considering the individual patient as a statistical unit and the dependencies of site data within a patient.

A variance components model (null model) was constructed using PD as the dependent variable but without inserting explanatory variables. The null model was used to estimate the overall variability of PD and to attribute it to the patient, tooth and site levels. The normality assumption of PD was verified and multicollinearity was performed. Subsequently, a series of explanatory variables were then entered into the model (covariate model). This further step allowed examination of the relationship between each covariate and the dependent variable. The fit change of each model (-2log likelihood) including /excluding explanatory variables was calculated and the significance was tested by chi-square analysis.

All data handling and statistical testing were performed with a software package (SPSS, Statistical Package for the Social Sciences, version 19, Chicago, IL). A statistical package designed specifically for multilevel modeling (Multilevel Models Project Institute of Education, MLwiN, version 2.16, London, U.K) was used to investigate the influence of subject, tooth and site-related covariates on the outcome variable.

\section{RESULTS}

A summary of each level variable is described in Table I. On average, participants were middle aged $(47 \pm 9$ years of age). The majority of the sample consisted of women (64.5\%), with normal weight (body mass index of $26 \pm 4.3$ ). A total of 444 patients were diagnosed with moderate $(n=256)$ and severe $(n=188)$ periodontitis. Additionally, control subjects without pockets and $\mathrm{CAL} \leq 2 \mathrm{~mm}$ were included (223 patients). Periodontal local infection was assessed by detection of periodontal pathogens in subgingival plaque; $63.7 \%$ of subjects tested positive for $\mathrm{P}$. gingivalis, $7.4 \%$ for $A$. actinomycetemcomitans, and $65.3 \%$ for T. forsythia. Our results indicated that periodontitis patients had detectable levels of $\lg G 1$ and $\lg G 2$. High $\lg G 1$ and IgG2 antibody levels against $A$. actinomycetemcomitans occurred in 16 and 17 periodontitis patients, respectively. High IgG1 and IgG2 antibody levels against $P$. gingivalis occurred in 136 and 147, periodontitis patients, respectively, and High IgG1 and IgG2 antibody levels against T. forsythia occurred in 137 and 153 periodontitis patients, respectively.

A total of 13.700 teeth and 82.200 sites were included in the multilevel analysis. In the null model variability at each individual level was obtained as percentage of the total variability calculated adding all estimates together (Table II). The majority of the variance was attributed to the site level (48\%), followed by the subject $(30 \%)$ and tooth level $(22 \%)$. Results from the variance component multilevel model with PD as the dependent variable, with significant explanatory covariates included, are presented in Table II. Significantly, better fit was obtained entering all clinical covariates at all levels.

Table I. Clinical and periodontal parameters by level (Subject, tooth, site).

\begin{tabular}{|c|c|c|}
\hline Parameter & & \\
\hline \multicolumn{3}{|l|}{ Subjects $(n=667)$} \\
\hline & Age (mean $\pm S D)$ & $47 \pm 9.1$ \\
\hline & Sex, Females & $64.5 \%$ \\
\hline & $\mathrm{BMI}, \mathrm{Kg} / \mathrm{m}^{2}$ & $26 \pm 4.3$ \\
\hline & $\mathrm{n}$ pockets $>4 \mathrm{~mm}$ & 21.358 \\
\hline & Aa presence & $7.4 \%$ \\
\hline & $P g$ presence & $63.7 \%$ \\
\hline & Tf presence & $65.3 \%$ \\
\hline & $\lg \mathrm{G} 1 \mathrm{Aa}$ & $16^{*}$ \\
\hline & $\lg G 2 A a$ & $17^{*}$ \\
\hline & $\lg 1 P g$ & $136^{*}$ \\
\hline & $\lg G 2 P g$ & $147^{*}$ \\
\hline & $\lg G 1 T f$ & $137^{*}$ \\
\hline & $\lg G 2 T f$ & $153^{*}$ \\
\hline \multicolumn{3}{|l|}{ Tooth $(n=13.700)$} \\
\hline & Anterior & 5.273 \\
\hline & Posterior & 8.427 \\
\hline \multicolumn{3}{|l|}{ Site $(n=82.200)$} \\
\hline & PD (mean $\pm S D)$ & $2.92 \pm 1.69$ \\
\hline & BOP (\%) & 51.4 \\
\hline & $\begin{array}{l}\text { Gingival erythema } \\
\text { percentage }\end{array}$ & 54.2 \\
\hline
\end{tabular}

$\mathrm{SD}=$ standard deviation; $\lg \mathrm{G}=$ immunoglobulin $\mathrm{G} ; \mathrm{Aa}=$ Aggregatibacter actinomycetemcomitans; Pg= Porphyromonas gingivalis; $\mathrm{Tf}=$ Tanerella forsythia; Periodontitis patients with High IgG. 
ARDILA, C. M.; GUZMÁN, I. C.; BERMUDEZ, L.; BERNAU, S.; CONTRERAS, A.; DUQUE, A.; DUARTE, S.; DE AVILA, J. \& LAFAURIE, G. I. Porphyromonas gingivalis and Aggregatibacter actinomycetemcomitans IgG subclass antibody levels as immunological risk indicators of chronic periodontitis: a multilevel approach. Int. J. Odontostomat., 7(3):433-440, 2013.

Regression estimates and significance testing for all clinical covariates were also performed. Table III depicts regression estimates for covariates. The multilevel analysis associated deeper probing depth with presence of serum IgG1 and IgG2 antibody to $P$. gingivalis and $A$. actinomycetemcomitans $(P=0.001$, $\mathrm{P}=0.002$, and $\mathrm{P}=0.001, \mathrm{P}=0.01$, respectively). This finding was corroborated by a regression analysis $(R R=1.98 \mathrm{Cl} 95 \% 1.10-3.58)$. No other subject variable was significant in the model.
At the tooth level, the model demonstrated that posterior teeth had higher PD compared to anterior teeth $(P=0.00001)$.

At the site level the model presented that mesial and distal sites were the areas where PD were greater than those observed at the buccal and lingual sites $(P=0.00001)$. Moreover, at the site level, BOP $(P=0.001)$ was significant in the model.

Table II. Multilevel linear regression model estimating the relative contribution of subject, tooth and site parameters to variability in Probing Depth (PD) increased.

\begin{tabular}{|c|c|c|}
\hline \multirow{3}{*}{ Intercept } & PD & \multirow{2}{*}{ Clinical Variables included } \\
\hline & Null model & \\
\hline & ß土SE & ß土SE \\
\hline & $2.935 \pm 0.037$ & $2.410 \pm 0.088$ \\
\hline \multicolumn{3}{|l|}{ Variance } \\
\hline Subject (Level 3) & $0.875 \pm 0.049$ & $0.578 \pm 0.34$ \\
\hline Tooth (Level 2) & $0.639 \pm 0.010$ & $0.491 \pm 0.008$ \\
\hline Site (Level 1) & $1.317 \pm 0.007$ & $1.293 \pm 0.007$ \\
\hline Total variance & 2.831 & 2.362 \\
\hline \multicolumn{3}{|c|}{ Percentage total variance } \\
\hline Subject (Level 3) & 30 & $24(-20 \%)^{\dagger}$ \\
\hline Tooth (Level 2) & 22 & $21(-5 \%)^{\dagger}$ \\
\hline Site (Level 1) & 48 & $55(+14.5 \%)^{\dagger}$ \\
\hline$-2 \mathrm{LL}$ & 315958.833 & $304765.044^{*}$ \\
\hline
\end{tabular}

$\ddagger$ Percentage of variance in the dependent variable PD attributed by the multilevel model at the patient, tooth, and site level.

† Difference in percentage of variance in the dependent variable PD at the patient, tooth, and site level when explanatory variables were included in the model.

*- 2 LL change significant $(P<0.00001)$ tested by $X^{2}$

Table III. Multilevel linear regression model assessing the significance of patient, tooth and site parameters in explaining the variability in Probing Depth increased.

\begin{tabular}{lcc}
\hline Parameters & PD $(\boldsymbol{B} \pm$ SE) & $P$ value \\
\hline Subject Level & & \\
IgG1Aa & $0.119 \pm 0.040$ & 0.001 \\
IgG2Aa & $0.094 \pm 0.045$ & 0.01 \\
IgG1Pg & $0.120 \pm 0.039$ & 0.001 \\
IgG2Pg & $0.121 \pm 0.042$ & 0.002 \\
Age, sex, BMI, IgG1 Tf, IgG2 Tf & ----- & $\mathrm{NS}$ \\
Aa, Pg, Tf & & \\
Tooth Level & & \\
Tooth position (posterior versus anterior) & $0.019 \pm 0.004$ & 0.00001 \\
Site Level & & \\
BOP & $0.498 \pm 0.011$ & 0.00001 \\
Surface (mesio-distal) & $0.055 \pm 0.018$ & 0.001 \\
Gingival erythema & --- & $\mathrm{NS}$ \\
\hline
\end{tabular}


ARDILA, C. M.; GUZMÁN, I. C.; BERMUDEZ, L.; BERNAU, S.; CONTRERAS, A.; DUQUE, A.; DUARTE, S.; DE AVILA, J. \& LAFAURIE, G. I. Porphyromonas gingivalis and Aggregatibacter actinomycetemcomitans IgG subclass antibody levels as immunological risk indicators of chronic periodontitis: a multilevel approach. Int. J. Odontostomat., 7(3):433-440, 2013.

Variances at subject and tooth levels were reduced in the random intercept models for either outcome, indicating that covariates explained some overall variations (Table II). The variances at the subject level were reduced most in proportion value compared to tooth level variances. These findings indicate that subject level covariates were better at explaining the variance of either outcome than were covariates at the tooth levels.

\section{DISCUSSION}

In order to account for the natural hierarchical structure of periodontal disease measurements, the present study adopted multilevel multiple regressions to investigate the relative contribution of $P$. gingivalis, A. actinomycetemcomitans and $T$. forsythia IgG subclass and other subject and local (tooth and site) factors on the probing pocket depth in subjects with chronic periodontitis. The majority of the variance was attributed to the site level (48\%), followed by the patient $(30 \%)$ and tooth level (22\%). This implies that most of the variations on the probing pocket depth result from factors acting at the site level. This is in agreement with previous studies also assessing the relative contribution of multilevel variation in clinical studies (D'Aiuto et al., 2005; Tomasi et al., 2007), which found that site-level factors had a much greater impact than subject-level factors. When explanatory variables were entered into the model, $55 \%$ of variance was attributed to variation between sites. Once again, similar results were shown using a multilevel model (D'Aiuto et al.; Tomasi et al.).

The results of the present study associated the increasing of PD with subject factors (serum IgG1 and IgG2 antibody to $P$. gingivalis and $A$. actinomycetemcomitans), tooth factors (tooth type) and site factors (mesio-distal position, BOP), confirming the evidence that outcomes at different sites and teeth within same patient are not independent (D'Aiuto et al.; Tomasi et al.).

To our knowledge no studies with multilevel approach have looked at the relative contribution of $P$. gingivalis and $A$. actinomycetemcomitans IgG subclass levels on the probing pocket depth in subjects with chronic periodontitis. Previous studies suggested that levels of $P$. gingivalis specific IgG1 and IgG2 are significantly elevated in the untreated periodontitis patients (Craig et al.; Sakai et al., 2001; Ebersole et al., 1996). Similarly, Craig et al. showed that increasing pocket depth is positively correlated with serum IgG antibody to $P$. gingivalis and it may be considered at risk factor for destructive periodontal disease progression. On the other hand, serum antibodies to A. actinomycetemcomitans were reported to be higher in patients with periodontitis (Gunsolley et al., 1988; Lu et al., 1994). Increased serum IgG2 levels have also been reported in subjects with pockets depth $\geq 5$ mm (Ebersole et al.; Gunsolley et al.). Moreover, Ebersole et al., indicated that local and/or systemic antibody responses are potent indicators of periodontal disease recurrence or progression. A longitudinal study also suggested that levels of serum antibodies to certain species over certain thresholds indicate the likelihood of disease activity taking place at some site in the oral cavity (Taubman et al.). As was shown in the present investigation, the correspondence between the risk factors for a subject and a site can be obtained by using multilevel analysis. However, longitudinal studies that include multilevel models in their analysis are needed.

The data analysis revealed that posterior teeth had higher PD than anterior teeth. Other investigators reported similar results using a multilevel model (Tu et al.). This finding seems to be consistent with the clinical observation that periodontitis patients often have more severe attachment loss at posterior sites (Reddy et al., 2000). Further, the finding of more rapid progression at posterior teeth is in agreement with the finding of partial edentulous being most common in the posterior region (Marcus et al., 1996).

At the site level, higher probing depths were observed for interdental sites compared to buccal and lingual sites. The results of the current investigation accord with a previous paper (Haffajee et al., 2007) and are consistent with the common setting of deeper pockets in the interproximal areas (Saiki et al.). Furthermore the presence of BOP at the tooth site level had a significant negative impact on PD. These findings corroborate data observed in other publications based on multilevel analysis (D'Aiuto et al.; Tomasi et al.).

The measure of the risk factors in periodontal disease might provide an overall summary of the interaction between the microbial field and the host systemic immune response for a patient as a whole (Tu et al.). It is not necessary for these risk factors to play the same role in predicting disease progression both at the site and subject levels (Mancl et al., 2000). 
ARDILA, C. M.; GUZMÁN, I. C.; BERMUDEZ, L.; BERNAU, S.; CONTRERAS, A.; DUQUE, A.; DUARTE, S.; DE AVILA, J. \& LAFAURIE, G. I. Porphyromonas gingivalis and Aggregatibacter actinomycetemcomitans IgG subclass antibody levels as immunological risk indicators of chronic periodontitis: a multilevel approach. Int. J. Odontostomat., 7(3):433-440, 2013.

These results emphasize the importance of bearing in mind factors related to the individual periodontal site in predicting disease progression. Such an approach is also well in line with the recommendations in the Consensus Report on epidemiology and diagnosis (Armitage \& Offenbacher, 1996) which states that screening tests for periodontal disease will need to be targeted to the needs of the patients in a hierarchical manner.

Multilevel modeling presents immense promise as an analytical model for periodontal studies and should be considered in an extensive diversity for its contribution to data analysis. On the basis of this investigation, future studies focusing on different sitelevel variables are warranted.

\section{ACKNOWLEDGMENTS}

This study was supported by a grant from the Institute of Science and Technology, Francisco José de Caldas COLCIENCIAS (Grant No 1308-04-11854). The authors report no conflicts of interest related to this study.

ARDILA, C. M.; GUZMÁN, I. C.; BERMUDEZ, L.; BERNAU, S.; CONTRERAS, A.; DUQUE, A.; DUARTE, S.; DE AVILA, J. \& LAFAURIE, G. I. Niveles de anticuerpos subclase IgG de Porphyromonas gingivalis y Aggregatibacter actinomycetemcomitans como indicadores de riesgo inmunológico de periodontitis crónica: un enfoque multinivel. Int. J. Odontostomat., 7(3):433-440, 2013.

RESUMEN: Los niveles de anticuerpos en algunos patógenos periodontales están asociados con mayores niveles de marcadores inflamatorios. El propósito de este estudio fue examinar la contribución relativa de inmunoglobulina sérica $\mathrm{G}$ (IgG) factores de nivel de anticuerpos de subclase y factores locales en la profundidad del sondaje en periodontitis crónica. Se tomaron muestras de suero de 444 pacientes con diagnóstico de periodontitis moderada y grave y de 223 sujetos de control. Se determinaron los títulos de anticuerpos IgG subclase a Porphyromonas gingivalis (Pg), Aggregatibacter actinomycetemcomitans ( $\mathrm{Aa}$ ) y Tanerella forsythia (Tf) mediante inmunoensayo indirecto (ELISA). La contribución relativa de los pacientes, los dientes, y el sitio asociado a los parámetros en la profundidad de sondaje fueron evaluados con un modelo multinivel jerárquico. Los resultados indicaron que los pacientes con periodontitis tenían niveles detectables de IgG1 e lgG2. Altos niveles de anticuerpos IgG1 e lgG2 contra Aa fueron observados en 132 y 142 pacientes con periodontitis, respectivamente. Niveles altos de anticuerpos $\operatorname{lgG} 1$ e lgG2 contra Pg fueron detectados en 141 y 138 en pacientes con periodontitis respectivamente, y niveles altos de anticuerpos IgG1 e IgG2 contra Tf se produjeron en 121 y 136 pacientes con periodontitis, respectivamente. La mayor parte de la varianza se atribuyó a nivel de sitio (48\%). El análisis multinivel asociados a profundidad de sondaje con factores relacionados a los sujetos, anticuerpos (suero lgG1 e lgG2 Aa y Pg), factores de los dientes (tipo) y los factores del sitio (localización mesial - distal y sangrado al sondaje). Anticuerpos elevados de suero lgG1 e lgG2 Aa y Pg (factores de los sujetos) reflejan el estado de la enfermedad periodontal destructiva.

PALABRAS CLAVE: subclase IgG, periodontitis, anticuerpos, análisis multinivel.

\section{REFERENCES}

Armitage, G. C. Development of a classification system for periodontal diseases and conditions. Ann. Periodontol., $4(1): 1-6,1999$.

Armitage, G. C. \& Offenbacher, S. Consensus report on periodontal diseases: epidemiology and diagnosis. Ann. Periodontol., 1(1):216-22, 1996.

Ashimoto, A.; Chen, C.; Bakker, I. \& Slots, J. Polymerase chain reaction detection of 8 putative periodontal pathogens in subgingival plaque of gingivitis and advanced periodontitis lesions. Oral Microbiol. Immunol., 11(4):266-73, 1996.

Craig, R. G.; Boylan, R.; Yip, J.; Mijares, D.; Imam, M.; Socransky, S. S.; Taubman, M. A. \& Haffajee, A. D. Serum
IgG antibody response to periodontal pathogens in minority populations: relationship to periodontal disease status and progression. J. Periodontal Res., 37(2):13246, 2002.

D'Aiuto, F.; Ready, D.; Parkar, M. \& Tonetti, M. S. Relative contribution of patient-, tooth-, and site-associated variability on the clinical outcomes of subgingival debridement. I. Probing depths. J. Periodontol., 76(3):398-405, 2005.

Ebersole, J. L.; Cappelli, D.; Steffen, M. J.; Willmann, D. E. \& O'Dell, D. S. Host response assessment in recurring periodontitis. J. Clin. Periodontol., 23(3 Pt. 2):258-62, 1996. 
ARDILA, C. M.; GUZMÁN, I. C.; BERMUDEZ, L.; BERNAU, S.; CONTRERAS, A.; DUQUE, A.; DUARTE, S.; DE AVILA, J. \& LAFAURIE, G. I. Porphyromonas gingivalis and Aggregatibacter actinomycetemcomitans IgG subclass antibody levels as immunological risk indicators of chronic periodontitis: a multilevel approach. Int. J. Odontostomat., 7(3):433-440, 2013.

Gunsolley, J. C.; Tew, J. C.; Gooss, C. M.; Burmeister, J. A. \& Schenkein, H. A. Effects of race and periodontal status on antibody reactive with Actinobacillus actinomycetemcomitans strain Y4. J. Periodontal Res., 23(5):303-7, 1988.

Haffajee, A. D. \& Socransky, S. S. Attachment level changes in destructive periodontal diseases. J. Clin. Periodontol., 13(5):461-75, 1986

Haffajee, A. D.; Torresyap, G. \& Socransky, S. S. Clinical changes following four different periodontal therapies for the treatment of chronic periodontitis: 1 year results. J. Clin. Periodontol., 34(3):243-53, 2007.

Holmlund, A.; Hedin, M.; Pussinen, P. J.; Lerner, U. H. \& Lind, L. Porphyromonas gingivalis $(\mathrm{Pg})$ a possible link between impaired oral health and acute myocardial infarction. Int. J. Cardiol., 148(2):148-53, 2011.

Kinane, D. F.; Mooney, J. \& Ebersole, J. L. Humoral immune response to Actinobacillus actinomycetemcomitans and Porphyromonas gingivalis in periodontal disease. Periodontol. 2000, 20:289-340, 1999.

Loe, H. \& Silness, J. Periodontal disease in pregnancy. I. Prevalence and Severity. Acta Odontol. Scand., 21:53351, 1963.

Lu, H.; Wang, M.; Gunsolley, J. C.; Schenkein, H. A. \& Tew, J. G. Serum immunoglobulin $\mathrm{G}$ subclass concentrations in periodontally healthy and diseased individuals. Infect. Immun., 62(5):1677-82, 1994.

Marcus, S. E.; Drury, T. F.; Brown, L. J. \& Zion, G. R. Tooth retention and tooth loss in the permanent dentition of adults: United States, 1988-1991. J. Dent. Res., 75:68495, 1996.

Mancl, L. A.; Leroux, B. G. \& DeRouen, T. A. Between-subject and within-subject statistical information in dental research. J. Dent. Res., 79(10):1778-81, 2000.

Rams, T. E.; Listgarten, M. A. \& Slots, J. Actinobacillus actinomycetemcomitans and Porphyromonas gingivalis subgingival presence, species-specific serum immunoglobulin $\mathrm{G}$ antibody levels, and periodontitis disease recurrence. J. Periodontal Res., 41(3):228-34, 1996.

Reddy, M. S.; Geurs, N. C.; Jeffcoat, R. L.; Proskin, H. \& Jeffcoat, M. K. Periodontal disease progression. J. Periodontol., 71(10):1583-90, 2000.

Sakai, Y.; Shimauchi, H.; Ito, H. O.; Kitamura, M. \& Okada, $\mathrm{H}$. Porphyromonas gingivalis-specific IgG subclass antibody levels as immunological risk indicators of periodontal bone loss. J. Clin. Periodontol., 28(9):853-9, 2001.
Saiki, R.K.; Gelfand, D.H.; Stoffel, S.; Scharf, S. J.; Higuchi, R.; Horn, G. T.; Mullis, K. B. \& Erlich, H. A. Primer-directed enzymatic amplification of DNA with a thermostable DNA polymerase. Science, 239(4839):487-91, 1988.

Taubman, M. A.; Haffajee, A. D.; Socransky, S. S.; Smith, D. J. \& Ebersole, J. L. Longitudinal monitoring of humoral antibody in subjects with destructive periodontal diseases. J. Periodontal Res., 27(5):511-21, 1992.

Tomasi, C.; Leyland, A. H. \& Wennström, J. L. Factors influencing the outcome of non-surgical periodontal treatment: a multilevel approach. J. Clin. Periodontol., 34(8):682-90, 2007.

Tu, Y. K.; Gilthorpe, M. S.; Griffiths, G. S.; Maddick, I. H.; Eaton, K. A. \& Johnson, N. W. The application of multilevel modeling in the analysis of longitudinal periodontal data-part II: changes in disease levels over time. J. Periodontol., 75(1):137-45, 2004.

Correspondence to:

Carlos M. Ardila

Calle $64 N^{\circ} 52-59$

Medellín

COLOMBIA

Telephone: $57-4-2196760$

Fax: $\quad$ 57-4-2195332

Email: martinardila@gmail.com

Received: 11-04-2013

Accepted: 10-08-2013 